\title{
Trichodina modesta: an exotic ciliate in the Neotropical region parasitizing an unusual host
}

\author{
Trichodina modesta: exótico ciliado na região Neotropical parasitando hospedeiro não usual \\ Gustavo Moraes Ramos Valladão'; Luiz Gustavo Giannecchini²; \\ Maurício Laterça Martins ${ }^{3 *}$; Santiago Benites de Pádua ${ }^{4}$
}

\begin{abstract}
${ }^{1}$ Laboratório de Patologia de Organismos Aquáticos - LAPOA, Centro de Aquicultura, Universidade Estadual Paulista - CAUNESP, Jaboticabal, SP, Brazil

${ }^{2}$ Laboratório de Peixes Ornamentais, Centro de Aquicultura, Universidade Estadual Paulista - CAUNESP, Jaboticabal, SP, Brazil

${ }^{3}$ Laboratório de Sanidade de Organismos Aquáticos - AQUOS, Departamento de Aquicultura, Universidade Federal de Santa

Catarina - UFSC, Florianópolis, SC, Brazil
\end{abstract}

${ }^{4}$ Aquivet Saúde Aquática, São José do Rio Preto, SP, Brazil

Received January 13, 2015

Accepted February 5, 2015

\begin{abstract}
In this study, an important ornamental fish, Betta splendens (Osphronemidae), from three different Brazilian states was examined for parasitic infestations. Smears with parasites were impregnated with silver nitrate or stained using Giemsa for taxonomic evaluation. A disc-shaped trichodinid with a body diameter of $39.7 \pm 3.3 \mu \mathrm{m}$, adhesive disc diameter of $32.9 \pm 3.1 \mu \mathrm{m}$ and denticulate ring diameter of $19.5 \pm 2.0 \mu \mathrm{m}$ was found. The morphological characteristics resembled those of Trichodina modesta Lom, 1970, a species that shows clear host specificity for Cypriniformes. Until now, its occurrence was restricted to the Eurasian region. In the present study, a new host for T. modesta is reported and therefore the first occurrence of this species in the Americas. The parasite was possibly introduced into the Neotropical region through the exotic fish trade, especially of Cypriniformes used by aquarists. The distribution of this ciliate is discussed and a checklist of localities and hosts for the species is provided.
\end{abstract}

Keywords: Ornamental fish, Ciliophora, Trichodinidae.

\section{Resumo}

Neste estudo, o peixe ornamental Betta splendens (Osphronemidae) foi examinado a partir de três diferentes Estados brasileiros para infestaçóes parasitárias. Esfregaços contendo parasitos foram impregnados com nitrato de prata ou corados com Giemsa para avaliação taxonômica. Foi observado o tricodinídeo em forma de disco com 39,7 $\pm 3,3 \mu \mathrm{m}$ de diâmetro do corpo, disco adesivo com 32,9 $\pm 3,1 \mu \mathrm{m}$ e anel denticulado 19,5 $\pm 2,0 \mu \mathrm{m}$ de diâmetro. As características morfológicas foram semelhantes à Trichodina modesta Lom, 1970, uma espécie que apresenta especificidade de hospedeiro por peixes Cypriniformes com ocorrência na Região Euro-asiática. No presente estudo, um novo hospedeiro para T. modesta é reportado, assim como a primeira ocorrência da espécie na América. O parasito tem sido possivelmente introduzido na regiâo Neotropical com o comércio de peixes exóticos, principalmente Cypriniformes usados por aquariofilistas. A dispersão do ciliado é discutida e um "checklist" de localidades e hospedeiros apresentado.

Palavras-chave: Peixe ornamental, Ciliophora, Trichodinidae.

\footnotetext{
*Corresponding author: Mauricio Laterça Martins. Laboratório de Sanidade de Organismos Aquáticos - AQUOS, Departamento de Aquicultura,

Universidade Federal de Santa Catarina - UFSC, Rod. Admar Gonzaga, 1346,

CEP 88040-900, Florianópolis, SC, Brasil.

e-mail: mauricio.martins@ufsc.br
} 


\section{Introduction}

Betta splendens (Perciformes: Osphronemidae) is commonly farmed as an ornamental fish over the world. According to Monvises et al. (2009), commercialization of Betta spp. was valued at approximately US\$ 800,000 in Thailand alone in 2005, and also in July 2013. Ornamental fish production is of great economic importance worldwide, but there is a lack of scientific information on the diseases of these fish and dissemination of trichodinids in particular. Trichodina nigra Lom, 1961 (THILAKARATNE et al., 2003), Trichodina acuta Lom, 1961 (PIAZZA et al., 2006), Trichodina reticulata Hirschman and Partsch, 1955 (ALBALADEJO \& ARTHUR, 1989; MAHMOUD et al., 2009; MARTINS et al., 2012; HU, 2012), Trichodina nobilis Chen, 1963 (MARTINS et al., 2012), Trichodina luzhoues Hu, 2012, and Trichodina mutabilis Kazubski and Migala, 1968 (HU, 2012), have been reported in ornamental fish. However, only Trichodina sp. (THILAKARATNE et al., 2003) and T. acuta (PIAZZA et al., 2006) have been reported from Betta splendens.

Trichodina modesta Lom, 1970, was initially described in Hungary, Slovakia and the Czech Republic by Lom (1970), with subsequent reports from Russia (STEIN, 1982; ARTHUR \& LOM, 1984), Taiwan (BASSON \& VAN AS, 1994), Poland (WIERZBICKA, 1997; WŁASOW et al., 2003), United Kingdom (GAZE \& WOOTTEN, 1998), Turkey (ÖZER, 2007; ÖZTÜRK \& ÖZER, 2007), Germany (RÜCKERT et al., 2007), China (ZHAO \& TANG, 2007; LIU \& ZHAO, 2010; HAN \& ZHAO, 2011; TANG et al., 2013) and Bangladesh (KIBRIA et al., 2010). All of these reports were from countries in Europe and Asia. The hosts susceptible to T. modesta include Crossostoma lacustre, Misgurnus anguillicaudatus, Rhinogobius brunneus (BASSON \& VAN AS, 1994) and Aphanius danfordii (ÖZER, 2007). All of these species are appreciated as ornamental fish, and this also includes B. splendens. Trichodinid dispersion is facilitated through the ornamental fish trade between countries. Albaladejo \& Arthur (1989) have reported not only occurrences of T. reticulata and Trichodina sp. from ornamental fish, but also T. acuta, T. nobilis, T. nigra, Trichodina heterodentata Duncan, 1977, Tripartiella tilapiae Duncan, 1977, and Trichodinella epizootica Raabe, 1950, from farmed imported cyprinids. Consequently, exportation and importation of ornamental fish represents an important risk factor for parasite dispersion worldwide.

Trichodinid parasitism may cause lesions on its hosts under farming conditions as a result of rapid trichodinid proliferation. Pathological alterations such as hyperplasia of the secondary lamellae (YEMMEN et al., 2010, 2011), cellular desquamation, lamellar fusion (ABDEL-BAKI et al., 2011), subepithelial edema with epithelial displacement of the secondary lamellae (VALLADÃO et al., 2014) and gill necrosis (YEMMEN et al., 2011; VALLADÃO et al., 2013) are commonly associated with trichodiniasis. These ciliates are frequently associated with lesions on the body surface that lead to opportunistic bacterial infection and outbreaks of mortality (KHAN, 2009; VALLADÃO et al., 2013, 2014). Since few studies have been done on fish lesions caused by trichodinids, epidemiological studies need to be encouraged in order to establish prophylactic measures for avoiding dispersion of these fish pathogens worldwide.
This study evaluated the trichodinid fauna of B. splendens and registers T. modesta in the Americas. The distribution of this ciliate is discussed and a checklist of hosts and localities for the parasite is presented.

\section{Materials and Methods}

\section{Study area and fish}

Adult males of Betta splendens from Muriaé, Minas Gerais state ( $\left.21^{\circ} 7^{\prime} 49^{\prime \prime} \mathrm{S} ; 42^{\circ} 22^{\prime} 3^{\prime \prime} \mathrm{W}\right)(\mathrm{n}=42)$, from Ribeirão Preto, Sáo Paulo state ( $21^{\circ} 10^{\prime} 40^{\prime \prime} \mathrm{S}$; $\left.47^{\circ} 48^{\prime} 36^{\prime \prime} \mathrm{W}\right)(\mathrm{n}=28)$ and from Cascavel, Paraná state ( $24^{\circ} 57^{\prime} 20^{\prime \prime}$ S; $\left.53^{\circ} 27^{\prime} 19^{\prime \prime} \mathrm{W}\right)(\mathrm{n}=23)$ were examined. The fish had standard lengths of approximately $3.0 \mathrm{~cm}$ and only adult males were used in this assay for sampling. Each fish was kept separately in a two liter aquarium, avoiding contamination with others, and fed twice a day with Tetra ${ }^{\circledR}$ Color Tropical Granules ${ }^{\mathrm{TM}}$. Partial water changes of about $50 \%$ was done each day. Water parameters were kept at a $\mathrm{pH} 6.2$ and a temperature of $27^{\circ} \mathrm{C}$.

\section{Parasitic diagnosis}

The body surface and gills of fish were scraped for parasitological analysis and when the parasites were present the smears were impregnated with silver nitrate using Klein's method (KLEIN, 1958) or stained with Giemsa to observe the nuclear apparatus (LOM, 1958). The span was the measurement from the extremity of the blade to the extremity of the ray as described by Arthur $\&$ Lom (1984). All measurements are in micrometers and followed the recommendations of Lom (1958) and Van As \& Basson (1989) and analyzed using a Nikon E200 ${ }^{\circledR}$ photomicroscope equipped with the Moticam $2300^{\circledR}$ image capture system. The parasite measurements were made using ImagePro Plus ${ }^{\circledR} 4.1$ software. Minimum and maximum values are provided, followed in parentheses by arithmetic mean, standard deviation and number of specimens or structures measured. Schematic drawings of the denticles, as proposed by Van As \& Basson (1989), were produced by means of vectorization using CorelDraw ${ }^{\circledR}$ X6 software.

\section{Results}

\section{Parasite diagnosis}

The fish examined showed trichodinid prevalence of $55.9 \%$ and Piscinoodinium pillulare Lom, 1981 prevalence of 21.5\%, only in the fish from the states of São Paulo and Minas Gerais. No parasites were found in the fish from the state of Paraná.

\section{Trichodinid description}

The trichodinids were disc-shaped, with the following characteristics: body diameter 29.5 - 46.3 (39.7 \pm 3.3 ; 50); border membrane width $2.3-4.1$ (3.4 $\pm 0.4 ; 50)$; adhesive disc diameter 24.4 - 39.0 (32.9 $\pm 3.1 ; 50)$; denticulate ring diameter $14.5-23.4(19.5 \pm 2.0 ; 50)$; number of denticles 
19.0 - $24.0(22.0 \pm 1.0 ; 50)$; denticle length 3.7 - $6.2(4.6 \pm 0.6$; 50); blade length $3.3-5.6(4.4 \pm 0.6 ; 50)$; central part width $1.5-3.0(2.3 \pm 0.3 ; 50)$; ray length $2.7-4.6(3.5 \pm 0.4 ; 50)$; denticle span 8.0 - $12.5(10.2 \pm 1.0 ; 50)$; pins per denticle $5-6(5.6 \pm 0.5 ; 49)$; horseshoe-shaped macronucleus diameter 25.6 - 38.3 (31.6 \pm 2.9 ; 40); thickness $5.0-10.9(7.9 \pm 1.4 ; 40)$; and distance between macronucleus extremities $4.6-10.3(6.5 \pm 1.3$; 40).

In silver nitrate impregnated material (Figure 1a), the center of the adhesive disc is of similar appearance to the adhesive disc. The blade is sickle-shaped with a tangent point that is slightly flat and not totally parallel to the $y+1$ axis. The blade has a rounded apex, almost touching the $y+1$ axis (Figure $1 b-c)$. The blade apophysis is rarely observed but some specimens have a discrete apophysis situated between the blade and the central part (Figure 1c). The central part is triangular and rounded, filling half of the space between the $\mathrm{Y}$ and $\mathrm{y}-1$ axes. An indentation below the $\mathrm{X}$ axis in the central part is present in some specimens. The connection between the central part and the ray is short. The ray is slender and straight with a rounded point, parallel to the Y axes. Ray apophysis is present. A few specimens showed discreetly anterior or posterior-directed rays, with tips surpassing the $\mathrm{Y}$ axes. The nuclear apparatus has a horseshoe-shaped macronucleus and oval micronucleus situated in the $y+1$ position.

A checklist of the hosts for T. modesta is provided in Table 1, followed by a distribution map and the chronological order of the parasite reports (Figure 2). (a)

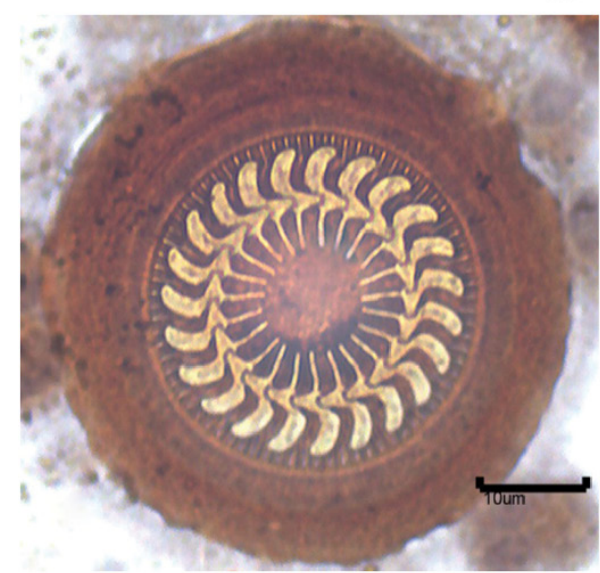

(b)

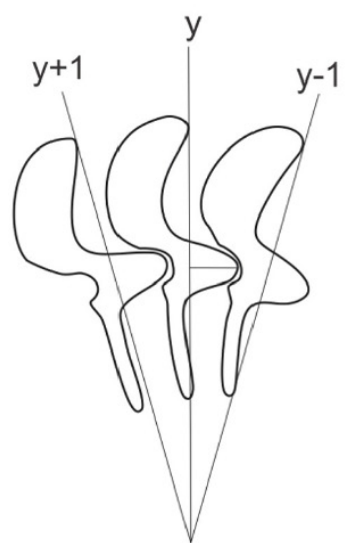

(c)

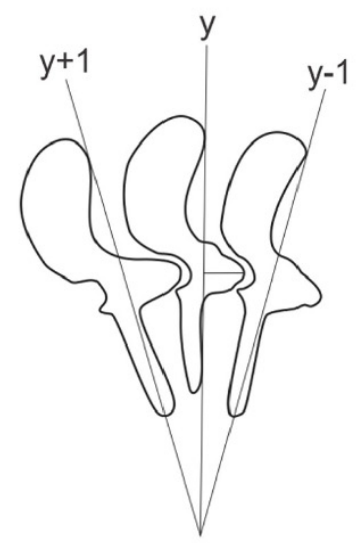

Figure 1. Adhesive disc of Trichodina modesta Lom, 1970, parasite of Betta splendens, impregnated with silver nitrate (a). Schematic drawing of the denticles of the present study $(b-c)$.

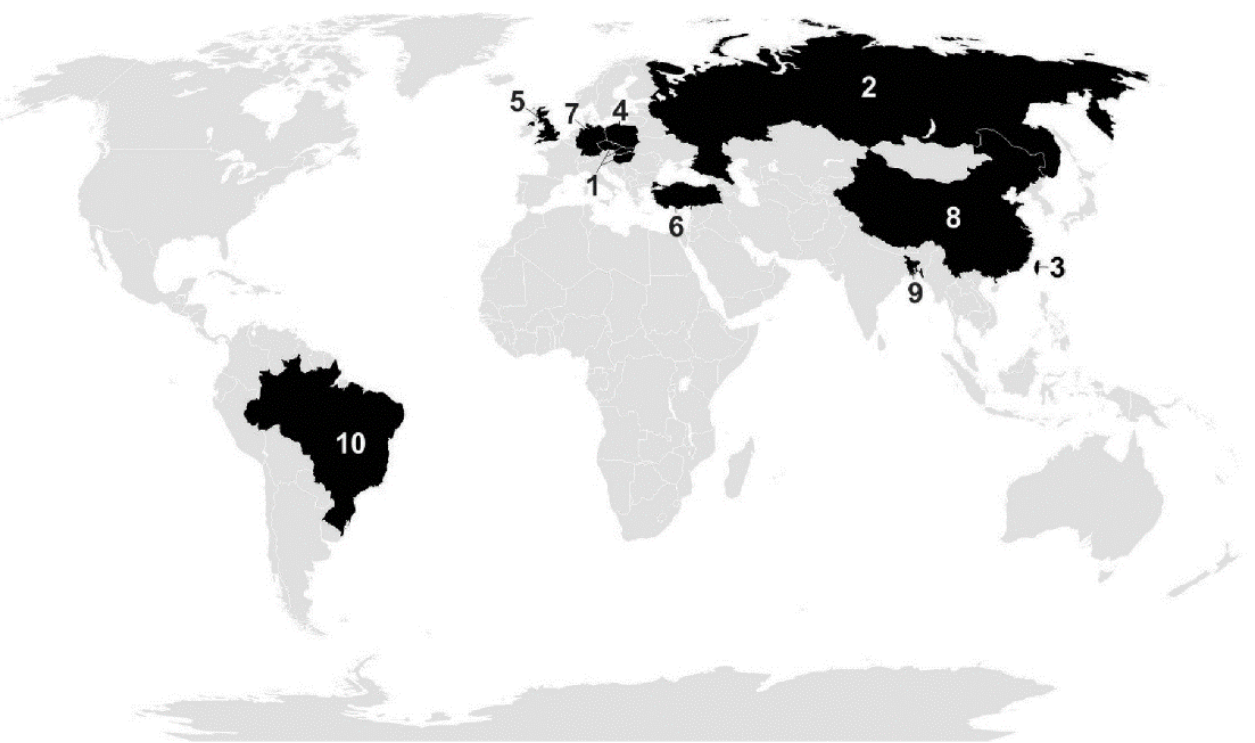

Figure 2. Worldwide dispersion of Trichodina modesta Lom, 1970. (1) Hungary, Slovakia and Czech Republic (Lom, 1970), (2) Russia (Stein, 1982; Arthur \& Lom, 1984), (3) Taiwan (Basson \& Van As, 1994), (4) Poland (Wierzbicka, 1997; Własow et al., 2003), (5) United Kingdom (Gaze \& Wootten, 1998), (6) Turkey (Özer 2007; Öztürk \& Özer 2007), (7) Germany (Rückert et al., 2007), (8) China (Zhao \& Tang, 2007; Liu \& Zhao, 2010; Han \& Zhao, 2011; Tang et al., 2013), (9) Bangladesh (Kibria et al., 2010) and (10) Brazil (present study). 
Table 1. Checklist of the hosts and localities of Trichodina modesta Lom, 1970.

\begin{tabular}{|c|c|c|c|c|}
\hline Order & Family & Host & Country & Author \\
\hline Cypriniformes & Cyprinidae & Abramis brama & Hungary & Lom (1970) \\
\hline Cypriniformes & Cyprinidae & Vimba vimba & $\begin{array}{c}\text { Slovakia and } \\
\text { Czech Republic }\end{array}$ & Lom (1970) \\
\hline Cypriniformes & Cyprinidae & Abramis brama & Russia & Stein (1982) \\
\hline Cypriniformes & Cyprinidae & Blicca bjoerkna & Russia & Arthur \& Lom (1984) \\
\hline Cypriniformes & Balitoridae & Crossostoma lacustre & Taiwan & Basson \& Van As (1994) \\
\hline Cypriniformes & Cobitidae & Misgurnus anguillicaudatus & Taiwan & Basson \& Van As (1994) \\
\hline Perciformes & Gobiidae & Rhinogobius brunneus & Taiwan & Basson \& Van As (1994) \\
\hline Cypriniformes & Cyprinidae & Abramis brama & Poland & Wierzbicka (1997) \\
\hline Cypriniformes & Cyprinidae & Blicca bjoerkna & Poland & Wierzbicka (1997) \\
\hline Cypriniformes & Cyprinidae & Abramis brama & United Kingdom & Gaze \& Wootten (1998) \\
\hline Cypriniformes & Cyprinidae & Tinca tinca & Poland & Własow et al. (2003) \\
\hline Cyprinodontiformes & Cyprinodontidae & Aphanius danfordii & Turkey & Özer (2007) \\
\hline Cyprinodontiformes & Cyprinodontidae & Aphanius danfordii & Turkey & Öztürk \& Özer (2007) \\
\hline Cypriniformes & Cyprinidae & Abramis brama & Germany & Rückert et al. (2007) \\
\hline Cypriniformes & Cyprinidae & Rutilus rutilus & Germany & Rückert et al. (2007) \\
\hline Cypriniformes & Cobitidae & Misgurnus anguillicaudatus & China & Zhao \& Tang (2007) \\
\hline Siluriformes & Schilbeidae & Clupisoma garua & Bangladesh & Kibria et al. (2010) \\
\hline Siluriformes & Bagridae & Pelteobagrus bleeker & China & Liu \& Zhao (2010) \\
\hline Cypriniformes & Cobitidae & Misgurnus anguillicaudatus & China & Han \& Zhao (2011) \\
\hline Cypriniformes & Cobitidae & Misgurnus anguillicaudatus & China & Tang et al. (2013) \\
\hline Perciformes & Osphronemidae & Betta splendens & Brazil & Present Study \\
\hline
\end{tabular}

\section{Discussion}

The present study reveals the presence of $T$. modesta, a parasite originally reported from the Eurasian region and now found in the Americas with a new and unusual host (B. splendens).

Since the first report of T. modesta in Hungary, Slovakia and the Czech Republic by Lom (1970), it has now also been found in several other Eurasian countries (Table 1). The morphological and morphometric characteristics of $T$. modesta described in the present study resemble the original description (LOM, 1970) and other records (WIERZBICKA, 1997; GAZE \& WOOTTEN, 1998; ÖZER, 2007). Despite the variation in the body diameter, $T$. modesta is classified as a small-sized (BASSON \& VAN AS, 1994; GAZE \& WOOTTEN, 1998; ZHAO \& TANG, 2007) or medium-sized trichodinid (WIERZBICKA, 1997; ÖZER, 2007; ÖZTÜRK \& ÖZER, 2007; present study). Morphometric variation may occur due to environmental and ecological factors in this ciliate group (KAZUBSKI, 1971). Previous studies found the parasite exclusively on the gills (LOM, 1970; ARTHUR \& LOM, 1984; WIERZBICKA, 1997). In contrast, in the present study, we have reported the presence of this parasite both on the gills and on the body surface, in a similar way to what was found by Basson $\&$ Van As (1994), Özer (2007) and Öztürk \& Özer (2007).

Gaze \& Wootten (1998) commented that T. modesta shows a high degree of host specificity, in comparison with other cosmopolitan trichodinids, for example $T$. heterodentata. From analyzing the reports in the literature, it seems that $T$. modesta shows specificity for the order Cypriniformes. Nevertheless, in the present study, the parasite was reported in an unusual fish, similar to that found by Basson \& Van As (1994), who also reported T. modesta in Perciformes fish. Two Silurifomes hosts found by Kibria et al. (2010) and Liu \& Zhao (2010) are further examples of its unusual occurrence.

Betta spp. is originally from Asia and it may have been responsible for the introduction of T. modesta into South America. On the other hand, because there are no reports of this trichodinid in the native area of this fish, this hypothesis could be challenged. Misgurnus anguillicaudatus has recently been found in natural Brazilian environments (GOMES et al., 2011), while Aphanius danfordii, Crossostoma lacustre and Rhinogobius brunneus are frequently found commercially in Brazilian pet shops. These are native fish in the endemic area for T. modesta and several studies have reported parasitism by this ciliate on these ornamental fish (BASSON \& VAN AS, 1994; ÖZER, 2007; ÖZTÜRK \& ÖZER, 2007; ZHAO \& TANG, 2007; HAN \& ZHAO, 2011; TANG et al., 2013).

From the above statements, it can be suggested that the introduction of $T$. modesta into the Neotropical region might be associated with large-scale commercial introductions of fish. It was also suggested by Van As \& Basson (1989) that T. heterodentata has become dispersed worldwide as a result of cichlid introductions into new localities. In addition, cyprinid introductions have also been responsible for dissemination of Lernaea cyprinacea in Brazil (PORTZ et al., 2013). Dispersion of fish and their parasites into new localities may increase the host diversity for parasitic infestations, thus supporting the recent findings of T. modesta in non-Cypriniformes fish such as those described by Kibria et al. (2010), Liu \& Zhao (2010) and in the present study. 
This study shows that most of the trichodinid parasites in South America need to be evaluated. It contributes towards improving the knowledge of the parasitic fauna of an important freshwater fish (B. splendens). Nevertheless, this is the first record of T. modesta in the Neotropical region and B. splendens is a new host for this ciliate. These data may infer the possibility of parasite introduction into the Americas via introductions of ornamental cyprinids.

\section{Acknowledgements}

We are grateful to Dr. ${ }^{\text {a }}$ Linda Basson (University of the Free State, South Africa) for scientific support and critical review, CNPq (National Council for Scientific and Technological Development) for grant to Dr. M.L. Martins (CNPq 302493/2010-7), FAPESP for scholarship to S.B. Pádua (2010/14490-1) and G.M.R. Valladão (2012/19414-7).

\section{References}

Abdel-Baki AS, Sakran T, Fayed H, Zayed E. Trichodina fahaka (Ciliophora: Peritrichia) in Tetradon fahaka from Nile River, Egypt: seasonality and histopathology. Sci Res Essays 2011; 6(7): 1583-1587.

Albaladejo JD, Arthur JR. Some trichodinids (Protozoa: Ciliophora: Peritrichida) from freshwater fishes imported into the Philippines. Asian Fish Sci 1989; 3(1): 1-25.

Arthur JR, Lom J. Trichodinid protozoa (Ciliophora: Peritrichida) from freshwater fishes of Rybinsk Reservoir, USSR1. J Eukaryot Microbiol 1984; 31(1): 82-91.

Basson L, Van As JG. Trichodinid ectoparasites (Ciliophora:Peritrichia) of wild and cultured freshwater fishes in Taiwan, with notes on their origin. Syst Parasitol 1994; 28(3): 197-222. http://dx.doi.org/10.1007/ BF00009518.

Gaze WH, Wootten R. Ectoparasitic species of the genus Trichodina (Ciliophora: Peritrichida) parasitising British freshwater fish. Folia Parasitol 1998; 45(3): 177-190. PMid:9805782.

Gomes CIDA, Peressin A, Cetra M, Barrella W. First adult record of Misgurnus anguillicaudatus, Cantor 1842 from Ribeira de Iguape River Basin, Brazil. Acta Limnol Bras 2011; 23(3): 229-232. http://dx.doi. org/10.1590/S2179-975X2012005000004.

Han X, Zhao Y. Study on Ectoparasitic trichodinids from cultured commercial fishes from Minjiang River Valley, Sichuan Province. $J$ Neijiang Univ 2011; 26(10): 22-31.

Hu Y. Ciliate ectoparasites (Ciliophora: Trichodinidae/Chilodonellidae) on gills of Carassius auratus from the Yangtze River, China, with the description of Trichodina luzhoues sp. n. Parasitol Res 2012; 111(1): 433439. http://dx.doi.org/10.1007/s00436-012-2859-0. PMid:22374308

Kazubski SL. Morphological variability of Semitrichodina sphaeronuclea (Lom, 1956). Acta Protozool 1971; 8(20): 251-259.

Khan RA. Parasites causing disease in wild and cultured fish in Newfoundland. Icel Agric Sci 2009; 22: 29-35.

Kibria MM, Islam H, Habib MMA, Shutradhar LC, Asmat GS. Trichodinid ectoparasites (Ciliophora: Trichodinidae) from the gills of freshwater fishes in the Shitalakhsya River, Bangladesh [online]. Kalyani: University of
Kalyani; 2010 [cited 2015 Abr 2]. Available from: http://www.klyuniv. ac.in/22ndncp/Proceedings\%20of\%2022nd\%20NCP_Kalyani.pdf.

Klein BM. The "dry" silver method and its proper use. J Protozool 1958; 5(2): 99-103. http://dx.doi.org/10.1111/j.1550-7408.1958.tb02535.x.

Liu C, Zhao Y. Morphological and taxonomic study on four species of trichodinids parasitic on gills of siluriformes fishes from freshwater. $J$ Chongqing Normal Univ 2010; 27(1): 16-21.

Lom J. A contribution to the systematics and morphology of endoparasitic trichodinids from amphibians, with a proposal of uniform specific characteristics. J Protozool 1958; 5(4): 251-263. http://dx.doi. org/10.1111/j.1550-7408.1958.tb02563.x.

Lom J. Observations on trichodinid ciliates from freshwater fishes. Arch Protistenkd 1970; 112: 153-177.

Mahmoud MA, Aly SM, Diab AS, John G. The role of ornamental goldfish Carassius auratus in transfer of some viruses and ectoparasites to cultured fish in Egypt: comparative ultra-pathological studies. Afr J Aquat Sci 2009; 34(2): 111-121. http://dx.doi.org/10.2989/AJAS.2009.34.2.1.888.

Martins ML, Marchiori N, Roumbedakis K, Lami F. Trichodina nobilis Chen, 1963 and Trichodina reticulata Hirschmann et Partsch, 1955 from ornamental freshwater fishes in Brazil. Braz J Biol2012; 72(2): 281-286. http://dx.doi.org/10.1590/S1519-69842012000200008. PMid:22735135

Monvises A, Nuangsaeng B, Sriwattanarothai N, Panijpan B. The Siamese fighting fish: well-known generally but little-known scientifically. Sci Asia 2009; 35(1): 8-16. http://dx.doi.org/10.2306/scienceasia1513-1874.2009.35.008.

Özer A. Trichodina modesta Lom, 1970 (Ciliophora: Peritrichia) infestations of an endemic toothcarp Aphanius danfordii Boulenger, 1890 (Pisces: Cyprinodontidae) in Sinop, Turkey. J Nat Hist 2007; 41(41-44): $2543-$ 2549. http://dx.doi.org/10.1080/00222930701739724.

Öztürk T, Özer A. Trichodinid fauna of the toothcarp Aphanius danfordii (Boulenger, 1890) (Osteichthyes: Cyprinodontidae), an endemic fish from Sarıkum Lagoon Lake in Sinop (Turkey). Acta Protozool 2007; 46: 73-80.

Piazza RS, Martins ML, Guiraldelli L, Yamashita M. Parasitic diseases of freshwater ornamental fishes commercialized in Florianópolis, Santa Catarina, Brazil. Bol Inst Pesca 2006; 32(1): 51-57.

Portz L, Antonucci AM, Ueda BH, Dotta G, Guidelli G, Roumbedakis $\mathrm{K}$, et al. Parasitos de peixes de cultivo e ornamentais. In: Pavanelli GC, Takemoto RM, Eiras JC, editors. Parasitologia de peixes de água doce do Brasil. Maringá: Eduem; 2013. p. 85-114.

Rückert S, Klimpel S, Palm HW. Parasite fauna of bream Abramis brama and roach Rutilus rutilus from a man-made waterway and a freshwater habitat in northern Germany. Dis Aquat Organ 2007; 74(3): 225-233. http://dx.doi.org/10.3354/dao074225. PMid:17465307

Stein GA. Parasitic ciliates (Peritrichida, Trichodinidae) of some fishes of the Kurish Gulf. Parazitologiya 1982; 16: 24-29.

Tang FH, Zhao YJ, Warren A. Phylogenetic analyses of Trichodinids (Ciliophora, Oligohymenophora) inferred from 18S rRNA gene sequence data. Curr Microbiol 2013; 66(3): 306-313. http://dx.doi.org/10.1007/ s00284-012-0274-5. PMid:23196703

Thilakaratne ID, Rajapaksha G, Hewakopara A, Rajapakse RP, Faizal AC. Parasitic infections in freshwater ornamental fish in Sri Lanka. Dis Aquat Organ 2003; 54(2): 157-162. http://dx.doi.org/10.3354/ dao054157. PMid:12747641

Valladão GMR, Gallani SU, De Pádua SB, Martins ML, Pilarski F. Trichodina heterodentata (Ciliophora) infestation on Prochilodus lineatus 
larvae: a host-parasite relationship study. Parasitology 2014; 141(5): 662669. http://dx.doi.org/10.1017/S0031182013001480. PMid:24476792

Valladão GMR, Pádua SB, Gallani SU, Menezes-Filho RN, Dias-Neto J, Martins ML, et al. Paratrichodina africana (Ciliophora): a pathogenic gill parasite in farmed Nile tilapia. Vet Parasitol 2013; 197(3-4): 705710. http://dx.doi.org/10.1016/j.vetpar.2013.04.043. PMid:23731856

Van As JG, Basson L. A further contribution to the taxonomy of the Trichodinidae (Ciliophora: Peritrichia) and a review of the taxonomic status of some fish ectoparasitic trichodinids. Syst Parasitol 1989; 14(3): 157-179. http://dx.doi.org/10.1007/BF02187051.

Wierzbicka J. Parasitic ciliates (Protozoa: Ciliophora) of the common bream, Abramis brama (L.) and white bream, Blicca bjoerkna (L.) from Dabie Lake (Poland). Acta Ichthyol Piscat 1997; 27(2): 145-153.

Własow T, Zmysłowska I, Lewandowska D, Mierzejewska K, Idzikowski R, Ziomek E. Bacteria and parasites on the gills of pike Esox lucius L. and tench Tinca tinca (L.) as indices of the trophic level of oœwin lake (Northeastern Poland). Arch Pol Fish 2003; 11(2): 225-235.

Yemmen C, Ktari MH, Bahri S. Seasonality and histopathology of Trichodina puytoraci Lom, 1962, a parasite of flathead mullet (Mugil cephalus) from Tunisia. Acta Adriat 2011; 52(1): 15-20.

Yemmen C, Quilichini Y, Ktari MH, Marchand B, Bahri S. Morphological, ecological and histopathological studies of Trichodina gobii Raabe, 1959 (Ciliophora: Peritrichida) infecting the gills of Solea aegyptiaca. Protistology 2010/2011; 6(4): 258-263.

Zhao Y, Tang F. Trichodinid ectoparasites (Ciliophora: Peritricha) from Misgurnus anguillicaudatus (Cantor) and Anodonta woodiana (Lea) in China, with descriptions of two new species of Trichodina Ehrenberg, 1838. Syst Parasitol 2007; 67(1): 65-72. http://dx.doi.org/10.1007/ s11230-006-9070-6. PMid:17294258 